\title{
SIMULASI POTENSI AIR TANAH PULAU PADANG RIAU DENGAN VISUAL MODFLOW
}

\author{
Teddy W Sudinda \\ Pusat Teknologi Lingkungan, BPPT, Kawasan Puspiptek, Tangerang Selatan, 15314, Indonesia \\ Email: teddy.sudinda@gmail.com
}

\begin{abstract}
ABSTRAK
Pulau Padang termasuk tipe pulau alluvium yang terbentuk di muara sungai, disusun oleh endapan sedimen dari hasil transportasi sungai. Untuk pengembangan wilayah dan otonomi daerah yang berdasarkan kepada pemanfaatan sumber daya alam, maka perlu penelitian tentang potensi air tanah untuk memenuhi kebutuhan air untuk berbagai keperluan. untuk mengetahui potensi air tanah telah dilakukan simulasi pemodelan air tanah dengan menggunakan software Modflow. Hasil simulasi pemompaan adalah berupa penurunan di sumur-sumur pemompaan yang dijadikan sumur observasi. Penurunan ini tidak mengartikan penurunan secara regional, tetapi hanya mewakili titik yang diobservasi saja. Kurva penurunan dengan berbagai skenario pemompaan telah dilakukan dengan beberapa alternatif sehingga diperoleh penurunan muka air tanah untuk akifer 1 dan akifer 2 . Untuk menghindari penurunan muka airtanah hingga di bawah laut maka debit maksimum pengambilan airtanah per titik disarankan adalah $1000 \mathrm{~m}^{3} /$ hari. Untuk kondisi aman maka pengambilan disarankan tidak melebihi $831 \mathrm{~m}^{3} / \mathrm{hari}^{\prime} / \mathrm{km}^{2}$.
\end{abstract}

Kata Kunci: Potensi Air tanah, Simulasi Pemompaan, Modflow

\section{SIMULATION OF GROUNDWATER POTENTIAL PADANG ISLAND, RIAU USING VISUAL MODFLOW}

\author{
Teddy W Sudinda \\ Center for Environmental Technology, BPPT, Puspiptek Area, South Tangerang, 15314, Indonesia \\ Email: teddy.sudinda@gmail.com
}

\begin{abstract}
The island of Padang, including the type of alluvium island, is formed at estuary, arranged by sediment deposits from the results of river transportation. For 'regional development and regional autonomy based on the utilization of natural resources, it is necessary to research the potential of ground water to meet water needs for various purposes. To find out the potential of ground water a groundwater modeling simulation has been carried out using Modflow software. Pumping simulation results are in the form of decreases in pumping wells that are used as observation wells. This decline does not mean a decline regionally, but only represents the observed point. The decreasing curve with various pumping scenarios has been carried out with several alternatives so as to obtain a decrease in groundwater level for akifer 1 and akifer 2. To avoid groundwater subsidence to below sea level, the maximum discharge of groundwater extraction per recommended point is $1000 \mathrm{~m} 3$ / day. For safe conditions, the recommended collection does not exceed $831 \mathrm{~m}^{3} /$ day $/ \mathrm{km}^{2}$.
\end{abstract}

Keywords: Groundwater Potential, Pumping Simulation, Modflow

\section{PENDAHULUAN}

Indonesia berupa kepulauan yang terdiri dari beribu - ribu pulau, pulau - pulau yang besar antara lain adalah P. Jawa, Sumatera, Kalimantan, Sulawesi dan Irian. Kemudian pulau - pulau Pulau Bali, Lombok Sumba, Sumbawa, Flores dan lain sebagainya selain pulau - pulau tersebut diatas, terdapat juga pulau - pulau kecil. Pengertian pulau kecil adalah pulau yang mempunyai luas kurang dari $2.000 \mathrm{~km}$ dan lebarnya $20 \mathrm{~km}$, sedangkan pulau - pulau dengan luas kurang dari $100 \mathrm{~km}$ disebut pulau sangat kecil. Permasalahan di pulau - pulau kecil yang dihuni oleh penduduk adalah kesulitan mendapatkan air bersih untuk berbagai keperluan. Bahkan banyak penduduk yang memanfaatkan air hujan untuk air minum pada waktu musim hujan. Ada juga beberapa pulau kecil yang mempunyai curah hujan relatif tinggi, tetapi pada musim hujan mengakibatkan terjadinya banjir dan sebaliknya pada musim kemarau kesulitan air. Kondisi ini adalah pengaruh keadaan alam dan sangat tergantung pada besarnya curah hujan dan jenis litologi batuan yang menyusun pulau tersebut. 
Pulau Padang - Kabupaten Bengkalis Propinsi Riau Kepulauan termasuk wilayah yang mempunyai potensi sumber alam minyak dan gas di Selat Malaka. Sumur-sumur minyak tersebar di pulau Padang, pulau Tebing Tinggi dan juga sumur-sumur minyak lepas pantai di selat Lalang yang dikendalikan dari Kurau-Pulau Padang. Pulau ini mempunyai luas $1.100 \mathrm{~km}^{2}$ dengan jarak terpanjang pulaqu arah utara-selatan $60 \mathrm{~km}$ dan jarak rata-rata arah timur-barat $20 \mathrm{~km}$ sehingga termasuk dalam kategori pulau kecil. Pulau ini dihuni pada beberapa tempat oleh penduduk lokal terutama di daerah Malibur pantai bagian Timur Pulau.

Pulau Padang termasuk tipe pulau alluvium yang terbentuk di muara sungai, disusun oleh endapan sedimen dari hasil transportasi sungai. Dalam rangka pengembangan wilayah dan otonomi daerah yang berdasarkan kepada pemanfaatan sumber daya alam, maka perlu penelitian tentang potensi air tanah untuk memenuhi kebutuhan air untuk berbagai keperluan. untuk mengetahui potensi air tanah telah dilakukan simulasi pemodelan air tanah dengan menggunakan software Modflow.

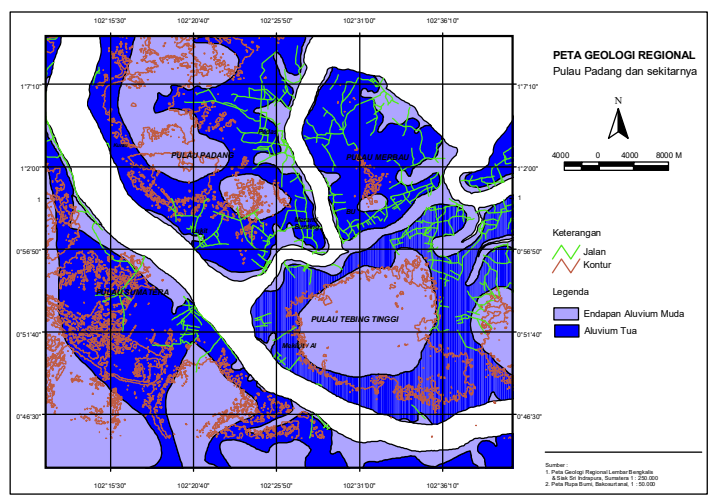

Gambar 1. Peta Geologi Regional (Cameron, N. R., dkk., 1982)

\section{TINJAUAN PUSTAKA}

\subsection{Geologi Regional}

Berdasarkan peta topografi skala 1:50.000 yang dikeluarkan oleh Bakosurtanal, morfologi daerah penelitian relatif landai dengan ketinggian antara $0 \mathrm{~m}$ dpl sampai $25 \mathrm{~m} \mathrm{dpl}$ ).

Berdasarkan geologi regional lembar Bengkalis dan Siak Sri Indrapura, yang dirangkum dari laporan geolistrik, maka daerah kajian tersusun oleh 2 satuan, yaitu:

a. Aluvium Tua (Old Alluvium), endapan ini merupakan 80 umeric 80 yang berumur plistosen atas dan menindih formasi minas secara tidak selaras. Material penyusunnya terdiri atas material lepas berbutir halus sampai kasar terdiri lempung, lanau, kerikil lempungan, sisa-sisa tumbuhan. b. Aluvium Muda (Young Alluvium), berumur Holosen sampai sekarang, terdiri dari lempung dan lanau pada endapan pantai, lumpur, pasir dan kerikil sisa-sisa tumbuhan yang diendapkan di dataran banjir aliran sungai. Juga terdapat terumbu koral. Gambar 1.

Peta geologi regional dapat dilihat pada

\subsection{Hidrogeologi Regional}

Hidrogeologi di Pulau Padang dan sekitarnya, menggambarkan kondisi yang 80umeric80, yaitu secara hidrogeologis akifer di daerah ini termasuk akifer produktif dengan penyebaran yang luas. Akifer produktif ini merupakan akifer dengan aliran melalui ruang antar butir, yaitu pada satuan batulumpur lunak dengan urat kaolin dan limonit, batulanau, lempung tufan, pasir dan kerikil, dengan kelulusan 80 umeric80 sedang.

Muka airtanah pada sistem ini umumnya dekat permukaan (dangkal) dan mengikuti topografi, dengan debit sumur mencapai lebih dari 5 liter / detik. Peta hidrogeologi regional daerah penelitian dapat dilihat pada Gambar 2.

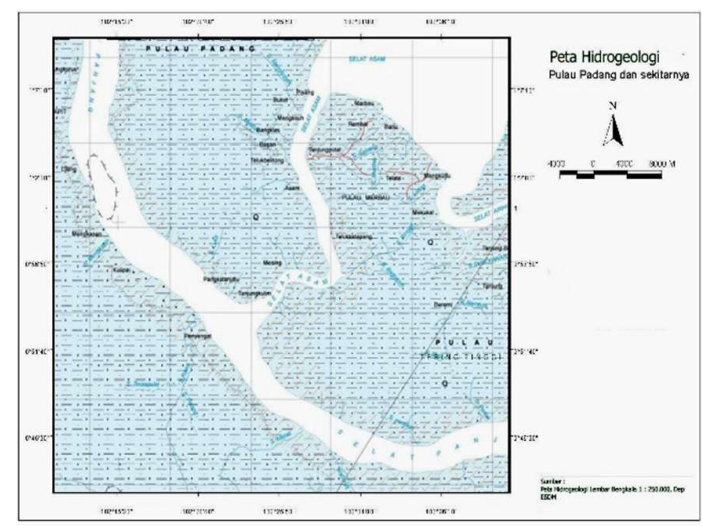

Gambar 2. Peta Hidroeologi Regional lembar

Bengkalis 1:250.00 (Mudiana, W., 2004)

\section{METODOLOGI}

Permodelan air tanah untuk Pulau Padang Riau dapat dipergunakan untuk meningkatkan pemahaman dan memberikan data kuantitatif tentang keberadaan sistem air tanah, termasuk didalamnya memperhitungkan dampak yang akan terjadi ketika suatu keputusan skema pengambilan diberlakukan.

Akuifer basin Pulau Padang terdiri atas akuifer dangkal atau akuifer tidak tertekan dan akuifer dalam atau disebut juga akuifer artesis atau akuifer tertekan. Akuifer dangkal biasanya mempunyai kedalaman antara 5 hingga 50 meter 
dan tidak tertekan, yakni ketinggian muka air mengikuti kontur muka tanah, sedangkan air tanah dalam biasanya terletak pada kedalaman dibawah 50 meter dan dalam keadaan tertekan, karena posisi air tanah ini terletak dibawah lapisan kedap air (confined layer). Untuk keperluan konsumsi domestik umumnya air tanah yang dimanfaatkan berasal dari air tanah dangkal, sedangkan untuk keperluan proses industri, menggunakan akuifer artesis.

Batas antara akuifer dangkal dan akuifer dalam biasanya tidak setegas yang dibayangkan. Didalam akuifer, lapisan tanah sangat heterogen. Antara satu lapis dengan yang lain tidak selalu berhubungan. Kadang kadang air tanah artesis terperangkap didalam suatu lensa akuifer, yang terisolir dengan yang lain, dan satu lapis akuifer dengan yang lain tidak selalu menerus. Untuk keperluan permodelan, batas antara lapis akuifer dengan yang lain diasumsikan merupakan suatu garis yang tegas, baik antara akuifer dangkal dengan akuifer artesis, maupun diantara akuifer artesis itu sendiri, karena pada lokasi tertentu terdapat lapisan akuifer artesis yang lebih dari satu (jamak). Oleh karena itu jika terdapat akuifer artesis jamak, maka lapisan akuifer itu akan dipisahkan (oleh cofining layer) menjadi beberapa lapis akuifer.

Ada beberapa aspek penting yang mempengaruhi akurasi permodelan air tanah. Aspek aspek tersebut antara lain adalah:

a. Keseimbangan tata air (water balance) : Sistem air tanah mempunyai masukan dan luaran, dimana masukan berupa air hujan yang merupakan imbuhan lokal terhadap akuifer dan imbuhan yang berasal dari hulu basin akuifer. Sedangkal luaran berupa ekstraksi baik untuk domestik maupun non domestik dan menjadi baseflow yang mengalir kesungai

b. Kondisi batas (boundary conditions): Didalam permodelan sistem air tanah dikondisikan sebagai suatu sistem yang tertutup, dimana sistem ini mempunyai batas fisik yang jelas, yang disebut kondisi batas, yakni suatu kondisi pada batas basin akuifer. Di batas basin dapat merupakan masukan air tanah kedalam akuifer ataupun luaran air tanah dari akuifer, ataupun suatu batas yang merupakan tembok yang tidak dapat ditembus (baik masuk maupun keluar).

c. Source and sinks, yakni penyebaran ekstraksi atau penyebaran imbuhan baik posisi, jumlah titiknya dan besarannya

d. Properti akuifer, yakni karakteristik akuifer yang berupa parameter tanah seperti porositas, konduktifitas hidrolis, dan kondisi geologis struktur tanahnya. e. Ukuran grid block. Untuk memudahkan melakukan permodelan, area studi dibagi menjadi beberapa gridblok, dimana gridblok ini dapat berupa bentuk geometris seperti eksagon, pentagon ataupun bujur sangkar dengan ukuran tertentu tergantung pada kondisi fisik lapangan. Besaran demensi gridblok ini menentukan akurasi dari hasil simulasi permodelan. Semakin kecil ukuran gridblok, semakin akurat hasil simulasinya.

f. Parameter model : Parameter model ini sangat spesifik yang ditentukan oleh metode pemrograman yang diterapkan, antara lain parameter yang menentukan interpolasi, koefisien numerik, ataupun beberapa parameter lain yang sengaja disisipkan kedalam model yang bertujuan untuk mengatur akurasi hasil model.

g. Kalibrasi dan validasi model : Sebelum model air tanah dapat digunakan untuk prediksi, harus dilakukan kalibrasi dan validasi untuk melihat bahwa hasil simulasi yang dikeluarkan oleh model dapat dipercaya (valid)

Model yang akan dipergunakan dalam melakukan simulasi air tanah basin Pulau Padang ini adalah MODFLOW. Adapun mesin penggerak dari model berawal dari persamaan gerak air tanah tiga dimensi, dengan asumsi densitas tetap, melalui media tanah yang berpori yang dideskripsikan melalui persamaan persamaan diferensial parsiil:

$$
\frac{\partial}{\partial x}\left(K_{x x} \frac{\partial h}{\partial x}\right)+\frac{\partial}{\partial y}\left(K_{y y} \frac{\partial h}{\partial y}\right)+\frac{\partial}{\partial z}\left(K_{z z} \frac{\partial h}{\partial z}\right)-W=S_{s} \frac{\partial h}{\partial t}
$$

Keterangan:

$K_{x x}, K_{y y}, K_{z z}=$ Konduktivitas hidrolis arah x, y dan $\mathrm{z}\left(\mathrm{Lt}^{-1}\right)$

$H \quad$ = tinggi piezometris air tanah (L)

$W \quad=$ Pemompaan $/$ penyuntikan $\left(\mathrm{Lt}^{-1}\right)$

$s_{s} \quad=$ Koefisien penyimpan 81 umeric 81 materi porus $\left(\mathrm{L}^{-1}\right)$

$t \quad=$ waktu $(\mathrm{t})$

Persamaan (1) kemudian dipecahkan secara numeric. Adapun metode yang dipergunakan adalah perbedaan berhingga (finite difference). Setelah persamaan disederhanakan menjadi persamaan aljabar linier kemudian diterjemahkan kedalam bahasa pemrograman fortran.

Sebagai asumsi awal, skenario simulasi adalah:

a. Kondisi batas : sebelah barat laut, head konstan dan recharge. Sebelah utara tidak ada aliran (no flow boundary). Sebelah tenggara head tetap (muka air laut). Sebelah selatan tidak ada aliran. 
b. Pengambilan air (ekstraksi) terkonsentrasi di pulau Padang Riau

c. Presipitasi terdistribusi merata diseluruh basin dan dianggap sebagai imbuhan yang bersifat lokal (dari muka tanah). Imbuhan alam juga terjadi dari sebelah barat laut.

d. Tidak ada kontaminasi air tanah, oleh karena itu simulasi model hanya dilakukan secara kuantitatif saja.

e. Parameter tanah didapatkan melalui hasil investigasi geologi teknik (data primer) dan parameter model berasal dari model itu sendiri.

\section{HASIL DAN PEMBAHASAN}

Berdasarkan peta Geologi yang dikeluarkan oleh Pusat Penelitian dan Pengembangan Geologi (PPPG) tahun 19xx, daerah penelitian tersusun oleh satuan batuan berumur kuarter (Qa) yang didominasi oleh pasir, lanau, hingga lempung yang belum mengalami kompaksi. Secara regional satuan aluvial ini di bagi dalam dua unit yaitu satuan aluvial muda dan aluvial tua. Secara umum tidak ditemukan kelurusan yang menunjukan adanya struktur geologi.

Berdasarkan investigasi geolistrik sampai kedalaman kurang lebih $150 \mathrm{~m}$, litologi daerah penelitian terbagi dalam 2 satuan litologi yaitu satuan pasir (sand dominated) dan satuan lempung (clay dominated). Litologi aluvial ini secara umum terbagi dalam tiga lapisan dengan kemiringan landai. Pada lapisan atas adalah satuan dengan dominasi pasir (sampai kedalaman $21 \mathrm{~m}$ bmt), lapisan kedua adalah satuan lempung (kedalaman antara 15 sampai 68 $\mathrm{m}$ bmt), lapisan ketiga kembali dominasi pasir (dari kedalaman antara $60 \mathrm{~m}$ hingga tidak diketahui). Berdasarkan interpretasi geolistrik yang sudah dilakukan akuifer 1 dan 2 merupakan fresh water. Profil susunan litologi daerah penelitian di titik geolistrik dan perkiraan satuan hidrogeologi daerah penelitian dapat dilihat pada Tabel 1, 2 dan 3.

Tabel 1. Profil Litologi dan Satuan Hidrogeologi di Pulau Padang, berdasarkan profil geolistrik P01.

\begin{tabular}{|r|r|l|l|}
\hline \multicolumn{2}{|c|}{ Depth } & \multirow{2}{*}{ Litologi } & \multicolumn{1}{c|}{$\begin{array}{c}\text { Satuan } \\
\text { Hidrogeologi }\end{array}$} \\
\hline 0.5 & 0.5214 & $\begin{array}{l}\text { Lapisan } \\
\text { Penutup }\end{array}$ & Akifer1 \\
\hline 0.5214 & 5.382 & Pasisan \\
\hline 5.382 & 5.598 & Pasir-kerikil & Akifer 1 \\
\hline 5.598 & 24.28 & $\begin{array}{l}\text { Lempung, } \\
\text { Lumpur }\end{array}$ & Akifer 1 \\
\hline 24.28 & 26.13 & $\begin{array}{l}\text { Akitard 1 } \\
\text { Lempung, }\end{array}$ & Akitard 1 \\
\hline 26.13 & 49.1 & $\begin{array}{l}\text { Lempur } \\
\text { Lumpur }\end{array}$ & Akitard 1 \\
\hline
\end{tabular}

\begin{tabular}{|c|c|c|c|}
\hline \multicolumn{2}{|c|}{ Depth } & \multirow{2}{*}{ Litologi } & $\begin{array}{c}\text { Satuan } \\
\text { Hidrogeologi }\end{array}$ \\
\cline { 1 - 2 } From & To & & Akifer 2 \\
\hline 49.1 & 138.2 & Pasir-kerikil & Akel \\
\hline
\end{tabular}

Tabel 2. Profil Litologi dan Satuan Hidrogeologi di P. Tebing Tinggi, berdasarkan profil geolistrik TT01.

\begin{tabular}{|c|c|c|c|}
\hline \multicolumn{2}{|c|}{ Depth } & \multirow{2}{*}{ Litologi } & \multirow{2}{*}{$\begin{array}{c}\text { Satuan } \\
\text { Hidrogeolog }\end{array}$} \\
\hline From & To & & \\
\hline 0 & 0.6 & Lapisan Penutup & Akifer 1 \\
\hline 0.6 & 1.32 & Lapisan Penutup & Akifer 1 \\
\hline 1.32 & 2.905 & Pasir-kerikil & Akifer 1 \\
\hline 2.905 & 6.394 & Pasir-kerikil & Akifer 1 \\
\hline 6.394 & 14.07 & Lempung,Lumpur & Akitard 1 \\
\hline 14.07 & 30.97 & Lempung,Lumpur & Akitard 1 \\
\hline 30.97 & 68.16 & Lempung,Lumpur & Akitard 1 \\
\hline 68.16 & 150 & Pasir-kerikil & Akifer 2 \\
\hline
\end{tabular}

Tabel 3. Profil Litologi dan Satuan Hidrogeologi di P. Merbau, berdasarkan profil geolistrik M01.

\begin{tabular}{|r|r|l|l|}
\hline \multicolumn{2}{|c|}{ Depth } & \multicolumn{1}{c|}{ Litologi } & $\begin{array}{c}\text { Satuan } \\
\text { Hidrogeologi }\end{array}$ \\
\hline From & \multicolumn{1}{c|}{ To } & & Akifer1 \\
\hline 0 & 0.5 & $\begin{array}{l}\text { Lapisan } \\
\text { Penutup }\end{array}$ & Akifer1 \\
\hline 0.803 & 1.94 & Pasir-kerikil & Akifer1 \\
\hline 1.94 & 7.01 & Pasir-kerikil & Akifer1 \\
\hline 7.01 & 18.2 & Pasir-kerikil & Akifer1 \\
\hline 18.2 & 54.8 & $\begin{array}{l}\text { Lempung, } \\
\text { Lumpur }\end{array}$ & Akitard 1 \\
\hline 54.8 & 64.4 & Pasir-kerikil & Akifer2 \\
\hline 64.4 & 142 & Pasir-kerikil & Akifer2 \\
\hline
\end{tabular}

Selanjutnya berdasarkan titik - titik pengukuran geolistrik (29 titik) direkonstruksi model 3 Dimensi untuk melakukan simulasi. Beberapa dasar asumsi simulasi numerik hidrogeologi adalah sebagai berikut:

1. Model konfigurasi akuifer sebagai model fisik dibangun berdasarkan data pengukuran geolistrik yang didukung dengan peta geologi regional

2. Morfologi model dibangun berdasarkan peta topografi Bakosurtanal dengan skala 1:50.000 dengan interval kontur $25 \mathrm{~m}$.

3. Model sistem airtanah adalah sistem airtanah bebas (unconfined) sampai semi confinedl leaky aquifer dimana lapisan pengekang lempung sebagai akitard, tidak sepenuhnya kedap karena masih dalam formasi satuan yang belum terkompaksi.

4. Model aliran mengikuti turunan persamaan Darcy untuk kondisi transient.

Dimana: $\mathrm{R}$ perubahan recharge atau discharge. Penyelesaian persamaan numerik ini dengan metode beda hingga (finite difference) grid centered dengan software modflow v. 3.1. 
5. Model dibangun dengan dimensi model 33 km (Easting) dan 26 km (Northing), dengan ukuran grid cell 100 meter $\times 100$ meter, jumlah grid cells $340 \times 270$ cells. Model ini meliputi sebagian Pulau Padang, Pulau Merbau, Pulau Tebing Tinggi dan sebagian kecil Pulau Sumatera.

6. Sebagai boundary condition digunakan constant head flow model Dirichlet Boundary (specified head) dalam model ini digunakan laut/ selat dengan muka tetap 0 $\mathrm{m}$ dpl.

7. Recharge dan evapotranspirasi dihitung di awal dimana net recharge (setelah dikurangi evapotranspirasi) adalah

8. Parameter akuifer (konduktivitas hidraulik) dihasilkan dari optimasi menggunakan trial and error pada kondisi steady, parameter konduktivitas hidraulik adalah $2.6 \times 10^{-5}$ $\mathrm{m} /$ det untuk Akuifer $1,10 \mathrm{x}^{-7} \mathrm{~m} /$ det untuk akuitard lempung, dan $1,38 \times 10^{-5} \mathrm{~m} /$ det untuk Akuifer 2.

9. Simulasi dilakukan selama 5 tahun untuk mengetahui kondisi neraca airtanah di Pulau Padang, Merbau, dan Tebing Tinggi. Skenario simulasi tanpa pengambilan airtanah, dan pengambilan airtanah di akuifer 1 dan 2 (dengan debit 712.927 $\mathrm{m}^{3} /$ hari). Dengan lokasi sebaran sumur diperkirakan berdasarkan peta tataguna lahan dimana sumur berada di daerah permukiman.

Model pembuatan simulasi dapat dilihat pada Gambar 3 dan Gambar 4 menunjukan Model 3 D Hidrostratigrafi dan Sebaran Pengambilan Airtanah.

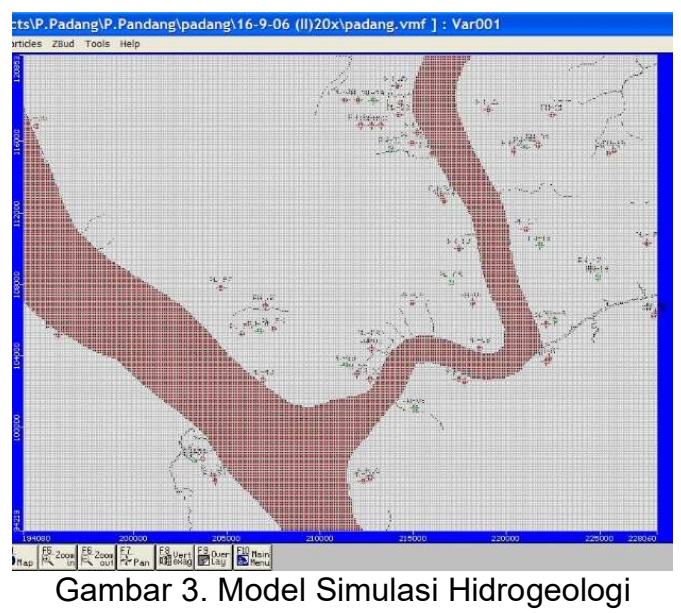

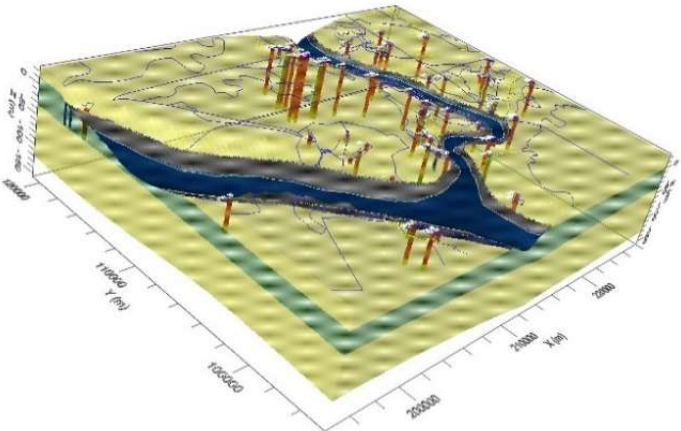

Gambar 4. Model 3D Hidrostratigrafi dan Sebaran Pengambilan Airtanah (Simulasi)

Simulasi hidrogeologi digunakan untuk mengetahui pola aliran airtanah, kecepatan aliran airtanah, serta neraca airtanah awal (tanpa eksploitasi) dan dengan aktivitas pengambilan airtanah. Dengan simulasi ini juga dapat diketahui prediksi penurunan aliran airtanah akibat pemompaan.

Pola aliran airtanah hasil simulasi dengan asumsi-asumsi diatas menghasilkan pola aliran airtanah yang dipengaruhi topografi, dimana aliran airtanah sesuai dengan kemiringan topografi. Kecepatan flux aliran airtanah alamiah rata-rata berkisar antara $10^{-6}$ sampai $10^{-8} \mathrm{~m} /$ detik atau sekitar $0,08 \mathrm{~cm} /$ hari sampai $8 \mathrm{~cm} /$ hari. Pola aliran airtanah di daerah yang disimulasikan dapat dilihat pada Gambar 5.

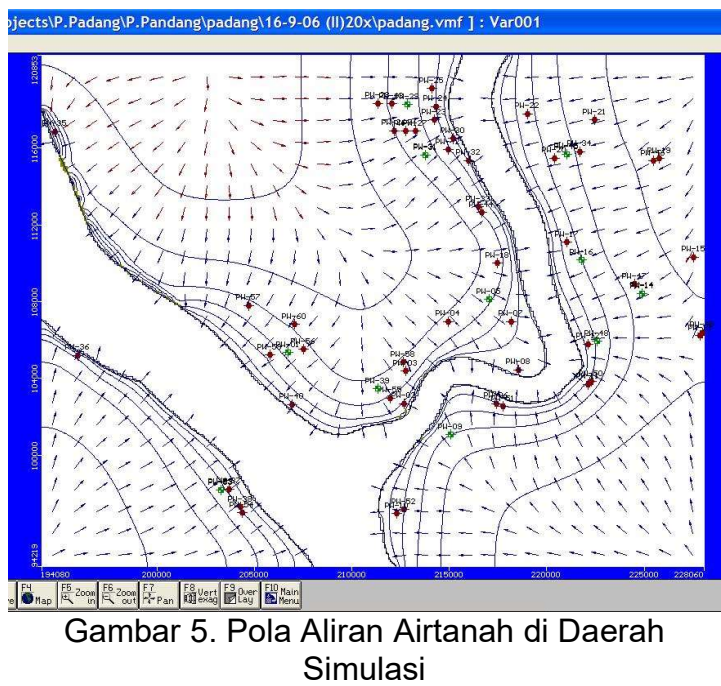

Potensi airtanah dihitung berdasarkan balance antara input (recharge/leaky) dengan output (discharge). Pada kondisi alamiah balance airtanah di lokasi study dapat dilihat pada Tabel 4. 
Tabel 4. Neraca Airtanah Pada Akuifer 1 dan 2

\begin{tabular}{|l|r|}
\hline \multicolumn{2}{|c|}{ Steady } \\
\hline Storage & IN ( $\mathbf{m}^{\mathbf{3}}$ /day) \\
\hline Constant Head & 552,093 \\
\hline Wells & 0 \\
\hline Drains & 0 \\
\hline Recharge & 0 \\
\hline River Leakage & 0 \\
\hline Stream Leakage & 0 \\
\hline General-Head & 0 \\
\hline Total & 712,927 \\
\hline
\end{tabular}

Dengan asumsi bahwa akuifer homogen (hasil dari penelitian geolistrik dan interpretasi dari peta hidrogeologi regional) maka potensi alamiah dari akuifer di lokasi tersebut secara alamiah adalah $712.927 \mathrm{~m}^{3} /$ hari atau $831 \mathrm{~m}^{3} / \mathrm{hari} / \mathrm{km}^{2}$ (dimana area simulasi $33 \times 26 \mathrm{~km}^{2}$ ). Simulasi ini juga menghasilkan prediksi penurunan airtanah di beberapa lokasi pusat pemompaan yang dipantau (yang diperkirakan berdasarkan peta tata guna lahan). Simulasi pemompaan dilakukan dengan skenario pemompaan dengan sebaran pompa seperti pada Gambar 3 untuk akuifer 1 dan akuifer 2 sebagai berikut, sedangkan sebaran sumur pantau dapat dilihat pada gambar 6 .

a. Simulasi dengan pemompaan sumur 100 $\mathrm{m}^{3} /$ hari

b. Simulasi dengan pemompaan sumur 400 $\mathrm{m}^{3} /$ hari

c. Simulasi dengan pemompaan sumur 1000 $\mathrm{m}^{3} /$ hari

d. Simulasi dengan pemompaan sumur 2000 $\mathrm{m}^{3} /$ hari

Berdasarkan hasil simulasi penurunan muka airtanah hanya berada di lokasi sekitar sumur eksploitasi saja, sedangkan penurunan muka airtanah secara regional region drawdown relatif kecil, hal ini dapat dilihat pada Gambar 6, dimana tidak ada kontur penurunan muka airtanah secara region (luas).

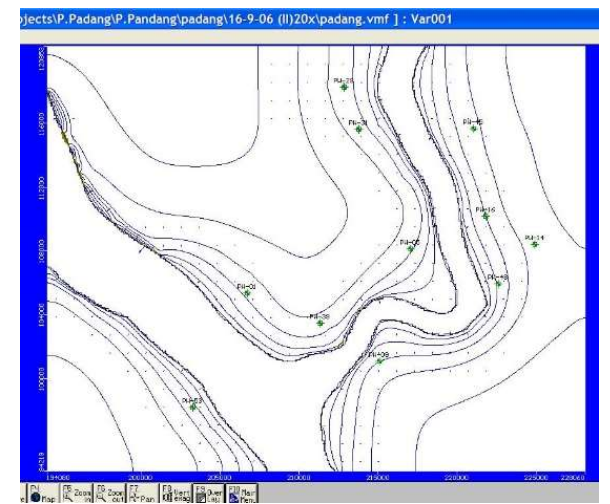

Gambar 6. Sebaran Sumur Pantau dan Kontur Muka Airtanah Akibat Pemompaan (interval kontur $5 \mathrm{~m}$ )
Hasil simulasi pemompaan adalah berupa penurunan di sumur-sumur pemompaan yang dijadikan sumur observasi. Penurunan ini tidak mengartikan penurunan secara regional/ area, tetapi hanya mewakili titik yang diobservasi saja. Kurva penurunan dengan berbagai skenario pemompaan tersebut dapat dilihat pada Lampiran.

Hasil dari simulasi dengan debit $100 \mathrm{~m}^{3} /$ hari ini pada akuifer 1 menunjukan penurunan maksimum $4 \mathrm{~m}$ di Sumur PW-53. Sedangkan penurunan pada sumur di Akuifer 2 maksimum 5 meter (PW-09), Pulau Tebing Tinggi. Dengan Simulasi ini semua muka airtanah baik akuifer 1 dan 2 dengan pemompaan kontinu selama 5 tahun masih di atas $0 \mathrm{~m} \mathrm{dpl}$ (terendah $9.7 \mathrm{mdpl}$ di akuifer 1). Hal ini menunjukan kondisi muka airtanah di akuifer diatas laut dan masih aman dari ancaman intrusi air laut.

Hasil dari simulasi dengan debit $400 \mathrm{~m}^{3} / \mathrm{hari}$ pada akuifer 1 menunjukan penurunan maksimum 5 meter (sumur PW-45) di Pulau Merbau. Sedangkan penurunan pada sumur di Akuifer 2 maksimum 8 meter (PW-29), Pulau Padang. Simulasi dengan debit $400 \mathrm{~m}^{3} /$ hari menunjukan bahwa muka airtanah terendah di sumur adalah 9,59 m dpl di akuifer 1 yang artinya muka airtanah relatif aman dari overpumping yang mengakibatkan intrusi airlaut.

Simulasi dengan debit $1000 \mathrm{~m}^{3} / \mathrm{hari}$ menunjukan penurunan maksimum 5 meter di akuifer 1 (PW-53), sedangkan penurunan di akuifer 2 relatif besar yaitu $16 \mathrm{~m}$ (PW-29) Pulau Padang. Muka airtanah terendah akibat pemompaan adalah 8,6 $\mathrm{m}$ dpl di akuifer 2, yang artinya muka airtanah relatif masih di atas muka air laut. Kondisi ini menunjukan potensi overpumping selama 5 tahun belum ada.

Simulasi dengan debit $2000 \mathrm{~m}^{3} / \mathrm{hari}$ menunukan penurunan maksimum 5 meter di akuifer 1 (PW-53), penurunan muka airtanah di sumur pada akuifer 2 cukup besar mencapai $30 \mathrm{~m}$ (PW-29). Muka airtanah terendah akibat pemompaan adalah $-7,7 \mathrm{~m}$ dpl di akuifer 2 . Kondisi ini menunjukan adanya potensi intrusi air laut karena potensial head akuifer berada di bawah $0 \mathrm{~m}$ dpl (laut).

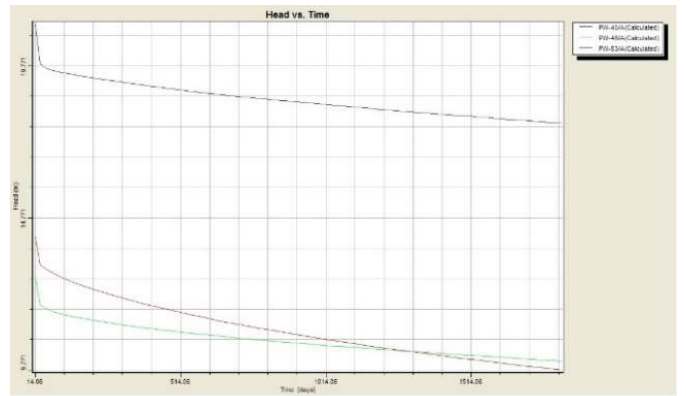

Gambar 7. Penurunan MAT di Akuifer 1 dengan Debit $100 \mathrm{~m}^{3} /$ hari 


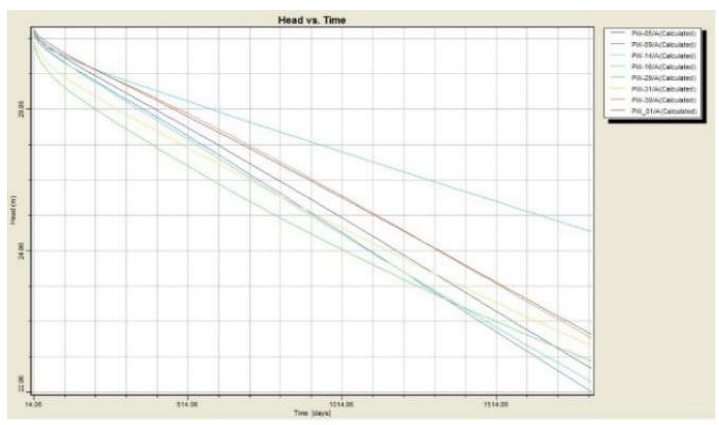

Gambar 8. Penurunan MAT di Akuifer 2 dengan Debit $100 \mathrm{~m}^{3} / \mathrm{hari}$

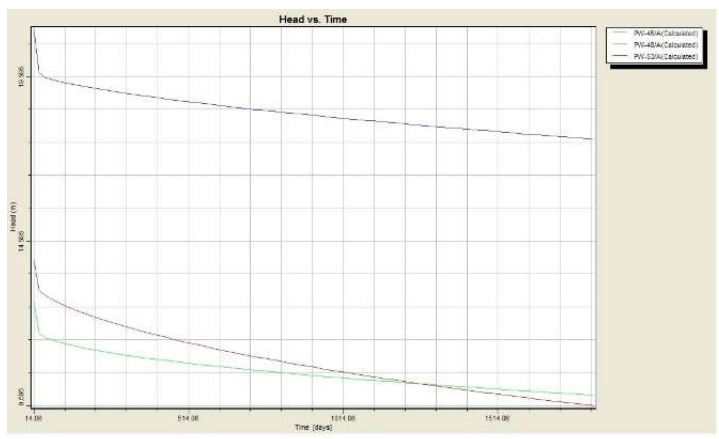

Gambar 9. Penurunan MAT di Akuifer 1 dengan Debit $400 \mathrm{~m}^{3} /$ hari

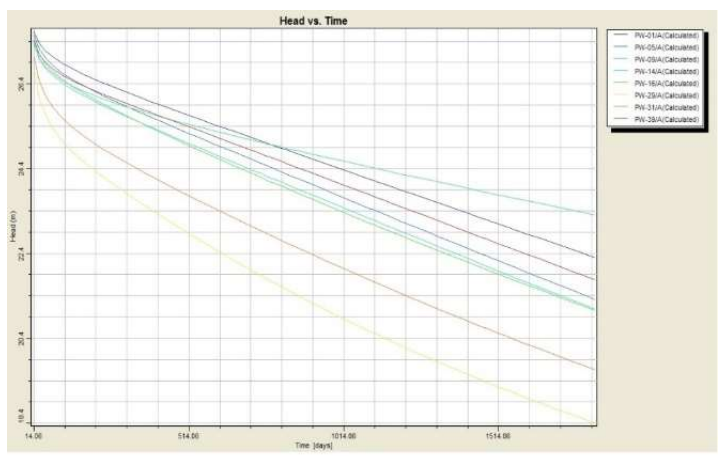

Gambar 10. Penurunan MAT di Akuifer 2 dengan Debit $400 \mathrm{~m}^{3} /$ hari

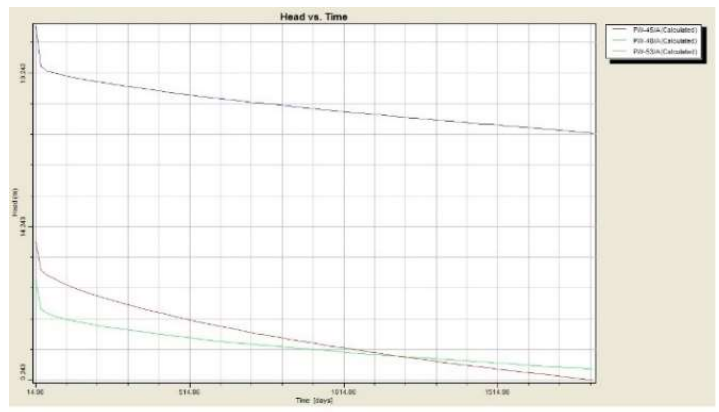

Gambar 11. Penurunan MAT di Akuifer 12 dengan Debit 1000 m³/hari

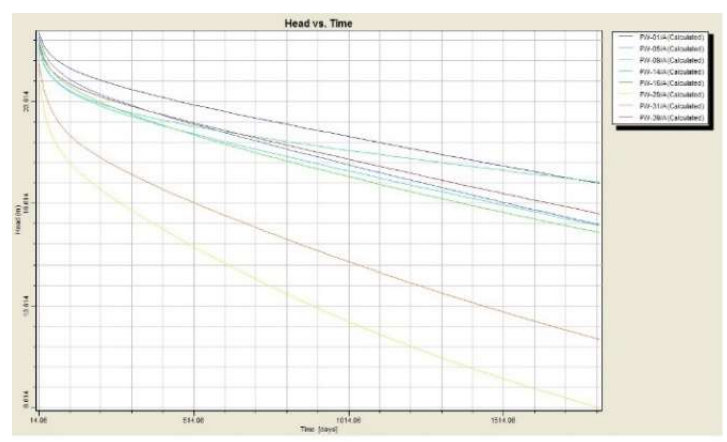

Gambar 12. Penurunan MAT di Akuifer 2 dengan Debit $1000 \mathrm{~m}^{3} /$ hari

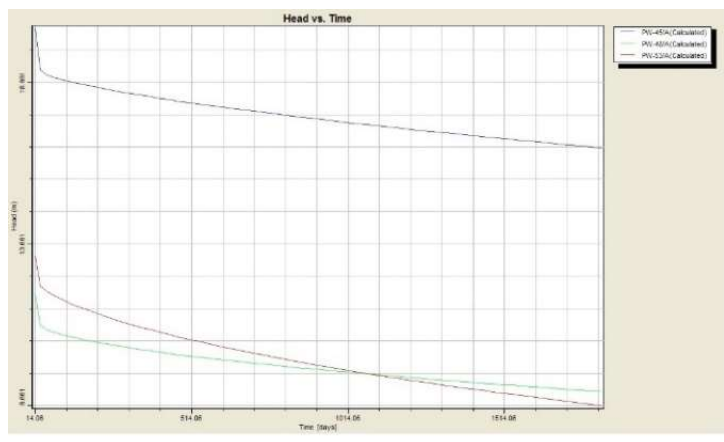

Gambar 13. Penurunan MAT di Akuifer 1 dengan Debit $2000 \mathrm{~m}^{3} / \mathrm{hari}$

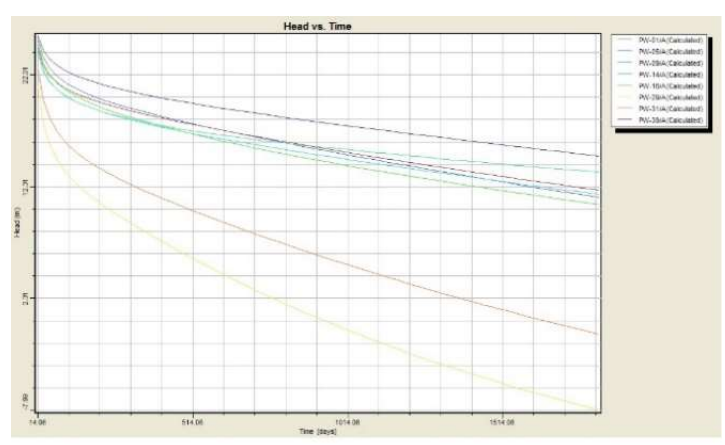

Gambar 14. Penurunan MAT di Akuifer 2 dengan Debit $2000 \mathrm{~m}^{3} /$ hari

\section{KESIMPULAN DAN SARAN}

Kesimpulan dari kajian potensi airtanah di P. Padang, P. Merbau, dan Pulau Tebing Tingg dengan menggunakan pemodelan dan simulasi adalah sebagai berikut:

a. Berdasarkan laporan studi geolistrik bahwa akuifer bukan merupakan air payau, maka secara kualitas relatif baik.

b. Berdasarkan simulasi numerik dengan modflow potensi alamiah airtanah yang dapat diambil adalah secara keseluruhan di area simulasi (P. Padang, P. Merbau, P. Tebing Tinggi, dan $P$. Sumatera) adalah $712.927 \mathrm{~m}^{3} / \mathrm{hari}$ atau sekitar 831 $\mathrm{m}^{3} / \mathrm{hari} / \mathrm{km}^{2}$ setara dengan 9,7 liter/detik/hari, dengan asumsi bahwa 
akuifer relatif homogen (berdasarkan penyelidikan geolistrik dan peta hidrogeologi.

c. Dengan simulasi pemompaan, 100, 400, 1000, dan $2000 \mathrm{~m}^{3} /$ hari, tidak terjadi penurunan muka airtanah secara regional.

d. Penurunan di akuifer 2 akan semakin besar di debit $400 \mathrm{~m}^{3} /$ hari, hal ini dikarenakan resapan alamiah akuifer kedua berasal dari leakage dari akuifer di atasnya, resapan yang tersingkap di permukaan di perkirakan jauh sehingga pengisian kembali akibat pemompaan lambat.

Saran dari kajian potensi airtanah di Pulau Padang, Merbau dan Tebing Tinggi adalah: Dengan simulasi menggunakan skenario pemompaan dengan debit 100, 400, 1000, dan $2000 \mathrm{~m}^{3} /$ hari maka pada pemompaan pada sumur dengan debit $2000 \mathrm{~m}^{3} /$ hari atau 23 liter/detik terjadi penurunan muka airtanah hingga muka airtanah mencapai -7,7 m dpl (dibawah laut).

Untuk menghindari penurunan muka airtanah hingga di bawah laut maka debit maksimum pengambilan airtanah per titik disarankan adalah $1000 \mathrm{~m}^{3} /$ hari. Untuk kondisi aman maka pengambilan disarankan tidak melebihi $831 \mathrm{~m}^{3} / \mathrm{hari} / \mathrm{km}^{2}$.

\section{DAFTAR PUSTAKA}

1. Elkrail, Adil Balla and Abdalla E. Ibrahim. 2008. Regional groundwater flow modeling of Gash River Basin, Sudan. Journal of Applied Sciences in Environmental Sanitation, 3 (3): 157-

2. Fetter, C.W., 2001. Applied Hydrogeology: Fourth Edition. Prentice Hall: United States of America

3. Harbaugh, Arlen W., Edward R. Banta, Mary C. Hill, and Michael G. McDonald. 2000. MODFLOW-2000, The U.S. Geological Survey Modular Ground Water Model: User Guide to Modularization Concepts and The
Ground Water Flow Process. United State: U.S. Geological Survey.

4. He, B., Keiji Takase, and Yi Wang. 2008. A Semi - distributed groudwater rechargemodeling for estimating watertable and water balance variables. Hydrogeology Journal 16: 1215-1228.

5. Herrmann, F., Christoph Jahnke, Florian Jenn, Ralf Kunkel, Hans-Jürgen Voigt, Jens Voigt, and Frank Wendland. 2009. Groundwater recharge rates for regional groundwater modelling: a case study using GROWA in the Lower Rhine lignite mining area, Germany. Hydrogeology Journal Vol. 17, Iss. 8; pg. 2049.

6. Illman, Walter A., Junfeng Zhu, Andrew J. Craig, and Danting Yin. 2010. Comparison of aquifer characterization approaches through steady state groundwater model validation: A controlled laboratory sandbox study. Journal of Geophysical Research, vol. 46.

7. Rojanschi, V., J. Wolf, and R. Barthel. 2006. Storage cascade vs. MODFLOW for the modelling of groundwater flow in the context of the calibration of a hydrological model in the Ammer catchment. Advanced in Geosciences, 9 , 101-108.

8. Straface, S., Enzo Rizzo, and Francesco Chidichimo. 2010. Estimation of hydraulic conductivity and water table map in a large-scale laboratory model by means of the self-potential method. Journal of Geophysical Research, vol. 115.

9. Todd, D.K dan Mays, L.W., 2005. GroundwaterHydrology: Third Edition. John Wiley \& Sons, Inc.: United States of America. 